Southern Methodist University

SMU Scholar

\title{
Teaching Contract Law: Introducing Students to a Critical Perspective Through Discussion of Indentured Servitude and Sharecropper Contracts
}

\author{
Gregory S. Crespi \\ Southern Methodist University, Dedman School of Law
}

\section{Recommended Citation}

Gregory S. Crespi, Teaching Contract Law: Introducing Students to a Critical Perspective Through Discussion of Indentured Servitude and Sharecropper Contracts (2011)

This document is brought to you for free and open access by the Faculty Scholarship at SMU Scholar. It has been accepted for inclusion in Faculty Journal Articles and Book Chapters by an authorized administrator of SMU Scholar. For more information, please visit http://digitalrepository.smu.edu. 


\section{TEACHING CONTRACT LAW: INTRODUCING STUDENTS TO A CRITICAL PERSPECTIVE THROUGH DISCUSSION OF INDENTURED SERVITUDE AND SHARECROPPER CONTRACTS}

by

Gregory Crespi 1

Preliminary Draft

August 10, 2011 
I have taught introductory contract law to first-year law students at Southern Methodist University for over 20 years. I, and presumably most other contract law teachers, start the first contracts course by explaining to students that contract law is primarily designed to facilitate a complex and efficient private ordering of society by providing a legal enforcement mechanism to encourage promisee reliance. This is the "happy face" story of contract law as a benign, facilitative social institution. However, before an instructor then turns to the details of the classical contract formation doctrines of offer, acceptance, mutual assent and consideration he should also provide the students with at least a brief exposure to a more critical perspective on contract law that calls to their attention some historical instances of its use as a means of social dominance and oppression. Unfortunately, not all contract law instructors do this. In my opinion those instructors who do not take the time to arm the students at the outset with both laudatory and critical perspectives that they can then bring to bear on their later detailed doctrinal studies are doing them a disservice.

As a means of introducing students to this complementary and more critical perspective on the subject I have upon occasion used the examples of indentures servitude contracts and sharecropper contracts in the USA. I present below for the reader's consideration a summary of a typical presentation I might make using these examples, during perhaps the third class of the semester, which presentation ordinarily takes about 20-30 minutes. In any particular class my remarks would of course be supplemented by any student comments and my responses thereto.

"As I have briefly explained to you over the past two classes, contract law is the legal framework through which society coercively enforces promises. This body of law has developed gradually over a number of centuries, and as I have told you the primary goal of contract law is to facilitate economic activity by encouraging and enabling people to enter into complex networks of promissory relationships and specialized activities. The public enforcement mechanism of contract law augments the availability of reputational sanctions as another means to encourage widespread promisee reliance on strangers to keep their promises, so that those complex promissory arrangements can be formed. It appears that contract law has worked reasonably well to achieve this end of widespread promisee reliance, with resulting benefits for almost everyone.

That is the "happy face" story of contract law. But this optimistic, laudatory depiction of contract law as a benign, facilitative social institution is not, however, the only story that can be told. There is definitely a darker side to the history of contract law. You need to realize that, in general, tools that are originally developed for a legitimate purpose are often later utilized for very different (and perhaps less benign) purposes, and that the overall contract law regime can be regarded as kind of a social "tool" that is no different from other tools in this regard.

Let me try to make this point in more concrete fashion. Consider this humble flat-head screwdriver I have in my hand. Why are there screwdrivers? What is their purpose? As far as the historians can determine, screwdrivers, of course along with screws, were originally developed sometime during the Middle Ages in Europe as a method to fasten two pieces of wood 
together. They proved to be quite popular and useful, and there probably are literally billions of screwdrivers now in use around the world! Almost everyone on earth has one or more screwdrivers around somewhere in a drawer or garage.

Once screwdrivers were invented, however, people quickly figured out that they also serve pretty well as pry bars. For example, you can use them to pry open new cans of paint, or partly-used cans of paint that are stuck shut. That's another benign use of that tool. Or, if you are so inclined, you can use a screwdriver to break into a locked house to rob it, without making a lot of noise, by prying open a window. Or, as another use, you can turn a common flat-head screwdriver into a pretty deadly weapon by sharpening the blade to a fine edge to create a dagger, and then use it to stab and kill somebody, which is unfortunately a fairly common practice in American prisons.

Now these latter two uses of screwdrivers are not the originally contemplated uses, to be sure, but they are ones for which it is well suited and often used. Not only every painter but also every burglar has a screwdriver in his tool bag, and many prisoners keep hidden somewhere in their cell a homemade dagger fashioned from a screwdriver! Therefore, if you want to make some sort of a overall judgment about the impact of screwdrivers on human welfare, you also need to consider the houses broken into with screwdrivers, and the prisoners stabbed, as well as the screws fastened and the paint cans opened with them!

Now an organized framework of legal rules is also a human creation, and is also a kind of a tool. And just like a screwdriver can also serve as a burglar tool or as a dagger, a set of legal rules that was originally created to achieve a certain benign objective can later be utilized by other people for a variety of other purposes, some of which may be somewhat dubious. Contract law is no exception to this. One can, for example, identify certain historical situations where the state's enforcement of promissory relationships, through the mechanisms of contract law, has served at least as much as a means of domination and oppression of one group of persons by another, as it has as a means for facilitating promisee reliance and productive activity.

Let me briefly give you a couple of American historical examples where contract law has been utilized in such an oppressive fashion. First of all, consider the "sharecropping" system of land tenure relationships that evolved in the southern United States after the Civil War, and which persisted until about World War II.2 Once the Union Civil War troops ended their occupation and returned north in the late-1870's, at the end of the Reconstruction Era, the white southern landowners then attempted to reassert their traditional domination and control of the local black populations that were now no longer their slaves. They were largely successful in this effort, and one important aspect of the new form that this reimposition of social domination took was the establishment of contractual, "sharecropping" land tenure arrangements, under which landless black families with no other means of subsistence would contract with white landowners to farm a portion of their land, and then pay over to them each year in rent a significant share of the resulting crop.

Now the terms of these contractual arrangements were generally very one-sided in favor of the landowners, as you might have expected, since the former slaves were destitute and 
largely illiterate and had few alternatives available, and thus had a very weak bargaining position. The contracts made little if any provision for suspending or reducing their rental payments in situations like droughts, hail storms, crop failures, etc. The net result, generally, was that over the years the sharecroppers would gradually get deeper and deeper in debt to the white landowners. If a sharecropper family in debt considered leaving the land and moving to a northern city like Chicago or Detroit by a "midnight train" to seek better economic opportunities, they were discouraged from this by the fact that if it became known that they were going to do this their few assets would be immediately seized by the local sheriff to pay their contractual debts, so they would have to leave with absolutely nothing, even if they could afford a train ticket.

What you had, in effect, was contract law being used as a legal mechanism to justify and facilitate the white landowners once again exercising broad, coercive control through the local courts and police force to exact rural farm labor from the local black population on oppressive terms. It proved to be a very useful tool for this purpose which, when exercised in conjunction with Jim Crow-type segregation laws, and with some extra-legal Ku Klux Klan terrorism and the occasional lynching of anyone who got too uppity, allowed the local white landowners to essentially maintain for another several generations the substance of the oppressive social relationships of the pre-Civil War slavery era. Eventually the creation of large numbers of factory job openings in cities like Chicago and Detroit in connection with the WWI and especially WWII defense mobilizations provided the southern blacks with a viable means of escape from these oppressive sharecropper social arrangements, and the sharecropper system eventually broke down as a result.

As another American historical instance where contract law was applied in an exploitative fashion, one about which you may not know as much about as you do about the sharecropper era, consider the experience of the American colonies between about 1630 and 1750, where there was extensive use of "indentured servitude" contracts. 3

Settling the new North American continent at that time was obviously very hard, dangerous, and unhealthy work! You had to chop down thick, brushy forests and drain swamps largely by hand, there were few creature comforts, there were lots of deadly epidemic diseases going round, and Indian attacks to worry about, and growing cotton and tobacco are at best very physically demanding work. Now lots of people were willing to be plantation owners in the new world, and sip mint juleps or other cool drinks on their porches while the workers were out laboring in the cotton fields, but very few people were voluntarily willing to be field hands working 14 hours a day in the swamps and the hot sun. After about 1750, as you know, the country relied primarily upon the large-scale enslavement of blacks from Africa to get the field hands for the tobacco and cotton fields, but in the century before 1750 there was heavy reliance upon white indentured servants to do the heavy field work.

The way the system operated is that recruiters would go through the English slums of London and Liverpool, which were in those days filled with starving, homeless people who had been displaced from their English villages by the enclosures of village grazing commons in connection with the industrial revolution (remember your Charles Dickens novels!), and would 
get them to sign contracts agreeing to work for an employer in the New World for 7 years, in exchange for ship passage and room and board during the 7-year work period, after which time they would be free to seek their fortunes amidst the many opportunities of the New World. However, the contracts were full of nasty fine print, as you might imagine, allowing the employers to impose harsh corporal punishment such as floggings and the like should the workers not do their assigned work, or attempt to quit before the 7 years were up, but starving people just looking for a chance to survive and maybe get a new start in life were willing to sign up, and of course most of them were illiterate and could not have read the contractual fine print even if they had tried to do so.

Now the term "indentured servant" may lead you to think of maids, nannies, butlers and the like, domestic servants in livery, but that is not what these people were forced to do. They were sent to live in shacks out in the fields and worked 14-hour days pulling stumps and clearing stones in the Virginia and South Carolina swamps! If they changed their minds about all of this after a while and tried to escape, they were arrested for willful breach of contract, were whipped by their employers, and often had their periods of servitude extended by the courts to compensate their employers for the costs of recapture. Many if not most of the indentured servants died of diseases or overwork before their term of indenture was complete. In other words, they lived an awful lot like the slaves that gradually displaced them in this kind of work over the next century, compliments of contract law!

Incidentally, the major reason that the "indentured servitude" system gradually went out of existence after about 1750 was that as New York and Philadelphia and Boston got to be fairsized cities, and as the Appalacian mountain lands began to be cleared of Indians and more open for settlement, it just got too easy for these "servants" to escape permanently and either work anonymously in the bustling new cities, or settle on their own small farms in the mountains. The historical origins of many of today's Appalacian Mountain communities are rooted in escaped indentured servants. It was much tougher for black slaves to escape and successfully hide out in the cities or the wilderness, because they stood out from other folks on account of their skin color, and unlike the English indentured servants they had no countrymen from their villages who spoke their language to provide aid and shelter.

That growing difference in recapture rates between escaped white servants and escaped black slaves tended to make white indentured servants increasingly more expensive than slaves for the planters, and that economic factor gradually led to formal master-slave relationships displacing contractual indentured servant relationships in the American South. Now my guess is that the 16th and 17th century English judges who, as we will see, collectively developed the basic contract law doctrines we use today, did not anticipate--and certainly did not intend--that those legal principles would be utilized to provide legal support to uphold oppressive indentured servitude or sharecropping relationships a couple of centuries later way across the Atlantic Ocean in America, but they were.

I am trying to make two points here that you should try to keep in mind throughout the course. One is the specific point that contract law has been used at times to ideologically justify and coercively enforce oppressive social relationships that are based on highly unequal 
bargaining power in the negotiation of those contracts. It has not always operated as a benign, facilitative institution that benefits almost everyone.

The broader and more general point that I am also trying to make, and that that you need to keep in mind, is that a framework of legal rules that is developed under one set of circumstances, to achieve a particular worthy social objective, may later be applied under very different circumstances by people who have different goals in mind than did the judges or legislators who originally developed those doctrines, sometimes with far less desirable results. Laws not only have their direct and intended effects, but also often have unintended and unforseen long-term effects. If you want to fully understand the consequences of a set of legal rules, or properly evaluate proposals for legal change, you need to keep this fact firmly in mind."

I recognize that the presentation of broad, contextual background material at the outset of a course always involves a cost. The trade-off here of course is that there will then be that much less time available in the semester for detailed doctrinal coverage. In my opinion, however, the long-term advantages for students of their being assisted at the outset in developing their abilities to step back from doctrinal details, and to reflect upon those doctrines' broader social context and consequences, are sufficiently great that some sacrifices in the coverage of doctrinal topics is warranted. This is particularly the case, in my opinion, when the contextual material helps students develop a critical perspective regarding the social consequences of various bodies of law, an aspect of legal education that is too often neglected, particularly in the contract law area.

1. Professor of Law, Dedman School of Law, Southern Methodist University. JD, Yale Law School, Ph.D., University of Iowa.

${ }^{2}$. For a comprehensive discussion of the use of sharecropping contracts in the USA, see generally [cite].

${ }^{3}$. For a comprehensive discussion of the use of indentured servitude contracts in the USA, see generally Michael A. Huffman II, They Were White and They Were Slaves (1991). 